\title{
PERBANDINGAN KINERJA ARTIFICIAL INTELLIGENCE DALAM MEMPREDIKSI KUAT TEKAN BETON.
}

\author{
Nico Christiono ${ }^{1}$ dan Doddy Prayogo ${ }^{2}$ \\ ${ }^{1}$ Mahasiswa Program Magister Teknik Sipil, Universitas Kristen Petra, Surabaya \\ ${ }^{2}$ Dosen Program Magister Teknik Sipil, Universitas Kristen Petra, Surabaya \\ ${ }^{1}$ nichtio@gmail.com, ${ }^{2}$ prayogo@petra.ac.id
}

\begin{abstract}
ABSTRAK: Dewasa ini, prediksi kuat tekan beton dapat dilakukan dengan bantuan artificial intelligence. Namun, metode prediksi manakah yang tepat digunakan untuk memprediksi kuat tekan beton masih menjadi pertanyaan. Maka, pada penelitian ini dilakukan evaluasi mengenai pemodelan metode prediksi yang paling akurat untuk memprediksi beragam campuran beton. Metode Al yang digunakan pada penelitian kali ini adalah artificial neural network (ANN), support vector machine (SVM), dan classification and regression tree (CART). Selain itu, digunakan satu metode tradisional, yaitu linear regression (LR). Selanjutnya, keempat metode ini dijalankan dengan beberapa pengaturan parameter dan dilakukan pengujian untuk empat macam dataset beton yang berbeda. Empat indikator error dan satu indikator normalisasi digunakan untuk mengevaluasi dan menentukan metode prediksi yang paling bagus. Dari hasil penelitian yang telah dilakukan, ANN memiliki performa yang paling baik bila dibandingkan dengan tiga metode prediksi lainnya. Hal ini dapat dilihat dari nilai error ANN yang lebih kecil bila dibandingkan dengan metode prediksi lainnya.
\end{abstract}

Kata kunci: prediksi kuat tekan beton, artificial intelligence, ANN, SVM, CART, LR

ABSTRCT: Today, concrete strength prediction can be conducted using artificial intelligence methods. Yet, deciding the best method for predicting concrete compressive strength remains an open question. Therefore, this research evaluates the most accurate prediction methods for predicting various datasets of concrete mixtures. In this study, three Al methods are used, namely, artificial neural network (ANN), support vector machines (SVM), and classification and regression tree (CART). In addition, a traditional method is used, that is, the linear regression (LR). Furthermore, these methods are run with several combinations of tuning parameters and tested with four different concrete datasets. Four error indicators and one normalization indicator are used to evaluate $\mathrm{Al}$ and determine the best $\mathrm{Al}$ method. The results indicate that ANN has the best performance compared with other methods. It can be seen that ANN produces smaller error values compared with the other methods.

Keywords: concrete strength prediction, artificial intelligence, ANN, SVM, CART, LR

\section{PENDAHULUAN}

Beton merupakan material utama dalam bidang konstruksi. Sebagai bahan utama penyusun sebuah konstruksi, kekuatan beton menjadi persyaratan yang harus dipenuhi agar bangunan yang akan dibuat tetap aman. Salah satu parameter kekuatan dari beton adalah kuat tekan beton, dimana kuat tekan rencana sebuah beton biasanya diambil pada umur 28 hari setelah pengecoran. Salah satu kendala dalam pembangunan yang menggunakan beton sebagai 
material utamanya adalah bagaimana kekuatan beton ini tercapai pada umur rencana tanpa menunggu hingga 28 hari umur beton tersebut. Karena dengan menunggu 28 hari, hal tersebut memakan biaya dan waktu (Kabir, Hasan, \& Miah, 2012).

Untuk menghindari waktu tunggu yang lama, prediksi kuat tekan beton diperlukan agar dapat mengetahui kuat tekan beton pada umur yang diharapkan. Prediksi kuat tekan beton sendiri sudah mulai dilakukan sekitar tahun 2000, di mana pada saat itu metode yang digunakan menggunakan persamaan rumus empiris (Duval \& Kadri, 1998). Salah satu metode prediksi tradisional yang sering digunakan untuk memprediksi kuat tekan beton adalah analisis regresi linier. Meskipun analisa regresi linier dapat menghasilkan model prediksi yang eksplisit, namun karena karakteristik dari material beton ini kompleks dan non-linear, maka analisis regresi kurang akurat untuk memprediksi kuat tekan beton (Yeh \& Lien 2009). Seiring berkembangnya zaman, penggunaan teknologi sudah banyak digunakan untuk membantu kerja manusia hingga melakukan prediksi kuat tekan beton ini sendiri.

Artificial intelligence (Al) merupakan suatu metode yang banyak sekali diteliti pada bidang ilmu teknik sipil. Beberapa penelitian pun sudah membuktikan bahwa penggunaan Al sudah sangat membantu untuk memprediksi kuat tekan beton (Azimi-Pour \& Eskandari-Naddaf, 2018; Behnood \& Golafshani, 2018; Hammoudi, Moussaceb, Belebchouche, \& Dahmoune, 2019; Khosravani, Nasiri, Anders, \& Weinberg, 2019; Prayogo, Wong, \& Tjandra, 2018). Dalam prakteknya, terdapat banyak tipe Al yang digunakan untuk memprediksi kekuatan suatu campuran beton, antara lain artificial neural network (ANN) (Behnood \& Golafshani, 2018; Topçu \& Saridemir, 2008), response surface methodology (Hammoudi et al., 2019), genetic expression programming (Azimi-Pour \& Eskandari-Naddaf, 2018). Masih banyak lagi jenis metode berbasis Al yang dapat digunakan dalam hal prediksi kekuatan beton ini.

Penelitian mengenai prediksi kuat tekan beton dengan campuran silica fume sudah dilakukan oleh Behnood \& Golafshani (2018). Pada penelitian tersebut, prediksi yang dihasilkan ANN menunjukkan korelasi yang sesuai antara kuat tekan prediksi dengan kuat tekan kenyataan. Selain itu, penelitian mengenai beton fly ash juga dilakukan oleh Topçu \& Saridemir, (2008) di mana pada penelitian tersebut digunakan ANN dan fuzzy logic untuk memprediksi kekuatan beton. Hasil yang diperoleh melalui prediksi Al ini hanya berbeda sekitar 1-2 MPa dengan pengujian nyata. Selanjutnya, Pala, Özbay, Öztaş, \& Yuce (2007) juga melakukan penelitian dengan hasil yang memuaskan untuk memprediksi kuat tekan dari beton fly ash dan silica fume menggunakan ANN. Baru-baru ini, penelitian yang dilakukan oleh Prayogo et al. (2018) membuktikan bahwa pemodelan melalui support vector regression untuk memprediksi high performance concrete juga memiliki akurasi prediksi yang tinggi bila dibandingkan dengan nilai kenyataan laboratoriumnya.

Walaupun sudah banyak penelitian yang menggunakan Al dalam memprediksi campuran beton, namun hanya sedikit penelitian yang menggunakan beragam campuran beton guna dilakukan prediksi menggunakan AI. Di sisi lain, penelitian yang sudah dilakukan hanya menggunakan 1 pengaturan parameter dalam proses prediksinya. Oleh karena itu, pada penelitian kali ini dibandingkan tiga metode Al dan satu metode tradisional untuk mengetahui pemodelan mana yang paling bagus untuk memprediksi beragam mix design dari campuran beton. Selanjutnya, untuk semua metode prediksi yang digunakan, dilakukan evaluasi parameter mana yang paling sesuai untuk masing-masing metode dalam memprediksi berbagai macam dataset. Metode Al yang digunakan adalah ANN, support vector machine 
(SVM), classification and regression tree (CART). Begitu pula dengan satu metode tradisional, yaitu linear regression (LR). Selanjutnya setiap model prediksi dianalisis ketepatan prediksi dengan cara melihat nilai error yang dapat terjadi. Nilai error yang ditinjau antara lain: linear of correlation, mean absolute error, root mean squared error, mean absolute percentage error.

\section{METODE PREDIKSI}

\subsection{Linear Regression}

Linear regression (LR) menjelaskan mengenai keterkaitan antara dua atau lebih variabel (Chou, Farfoura, Chiu, \& Altaharwa, 2011). Rumusan yang dihasilkan pemodelan ini menunjukkan bidang dalam $n$-dimensi ruang, di mana $n$ adalah banyaknya variabel bebas. LR sendiri terdiri dari banyak variabel bebas, $X$, satu variabel terikat, $Y$, dan parameter, $b$ Perumusan dari LR dapat dilihat pada Persamaan (1).

$$
Y=b_{0}+b_{1} X_{1}+b_{2} X_{2} \ldots \ldots \ldots+b_{n} X_{n}+C
$$

Pada pemodelan yang dihasilkan, $Y$ menggambarkan kuat tekan dari beton, $b_{n}$ menggambarkan koefisien, $X_{n}$ menggambarkan variabel nilai dari semen, pasir, kerikil, blastfurnace slag, superplasticizer, air, dan lain sebagainya yang mempengaruhi kuat tekan dari beton. Selain itu, $C$ adalah konstanta yang dihasilkan dari analisa.

Metode LR sendiri juga sudah digunakan pada penelitian-penelitian terdahulu untuk mencari karakteristik dari beton (Chou, Tsai, Pham, \& Lu, 2014; Khademi, Akbari, Jamal, \& Nikoo, 2017). Nilai akurasi yang dihasilkan dari pemodelan ini cukup buruk karena dalam metode ini menggunakan analisa linier pada data-data beton yang cenderung non-linear (Chou et al., 2011). Bagaimanapun juga, karena mudahnya penggunaan metode ini, pada penelitian kali ini dilakukan analisa pada LR untuk membandingkan dengan hasil dari metode lain.

\subsection{Artificial Neural Network}

ANN adalah metode yang sudah dikenal sukses dalam hal prediksi. Metode ANN sendiri pertama kali diusulkan oleh Rosenblatt (1958) yang terinspirasi dari koneksi antar neuron dalam otak manusia yang tersusun atas beberapa elemen dalam layer. Penggunaan ANN dalam studi pun sudah banyak dilakukan (Cheng, Firdausi, \& Prayogo, 2014; Eskandari, Nik, \& Eidi, 2016; Hammoudi et al., 2019). ANN memiliki beberapa layer dalam komputasinya yaitu input layer, hidden layer, output layer. Input layer merepresentasikan komponen variabel dari beton, hidden layer menunjukkan titik-titik perhitungan, dan output layer menunjukkan kuat tekan beton yang akan diprediksi maupun yang sudah diprediksi. Gambar 1 menunjukkan gambaran singkat mengenai struktur pemodelan ANN.

Algoritma yang paling sering dipakai untuk memprediksi dalam ANN adalah Back-Propagation dimana algoritma ini mengatur faktor dari koneksinya dan nilai-nilai bias yang dapat muncul dalam proses training. Neuron yang aktif dalam hidden layer dapat dijelaskan dalam persamaan berikut:

$$
N e t_{j}=\sum W_{j i} X_{i} \quad \text { dan } \quad Y_{j}=f\left(\text { net }_{j}\right)
$$


dimana $n t_{j}$ adalah aktivasi dari neuron ke-j, iadalah himpunan neuron dari layer sebelumnya, $w_{j i}$ adalah pembobotan antara neuron $j$ dan neuron $i, x_{i}$ adalah output dari neuron ke- $i$, dan $y_{j}$ adalah fungsi transfer logistik

$$
f(n e t j)=\frac{1}{1+e^{-\lambda n e t j}}
$$

dimana $\lambda$ mengontrol fungsi dari gradien.

Perumusan untuk training dan pembaharuan bobot $w_{j i}$ dalam setiap siklus (h) adalah:

$$
w_{j i}(h)=w_{j i}(h-1)+\Delta w_{j i}(h)
$$

Selanjutnya, perubahan dari $\Delta w_{j i}(h)$ adalah:

$$
\Delta w_{j i}(h)=\eta \delta_{p i} x_{p i}+\alpha \Delta w_{j i}(h-1)
$$

Dimana $\eta$ adalah learning parameter, $\delta_{p i}$ adalah error, $x_{p i}$ adalah nilai output dari neuron $i, \alpha$ adalah momentum parameter, dan $\Delta w_{j i}(h-1)$ adalah perubahan dari $w_{j i}$ dalam siklus sebelumnya.

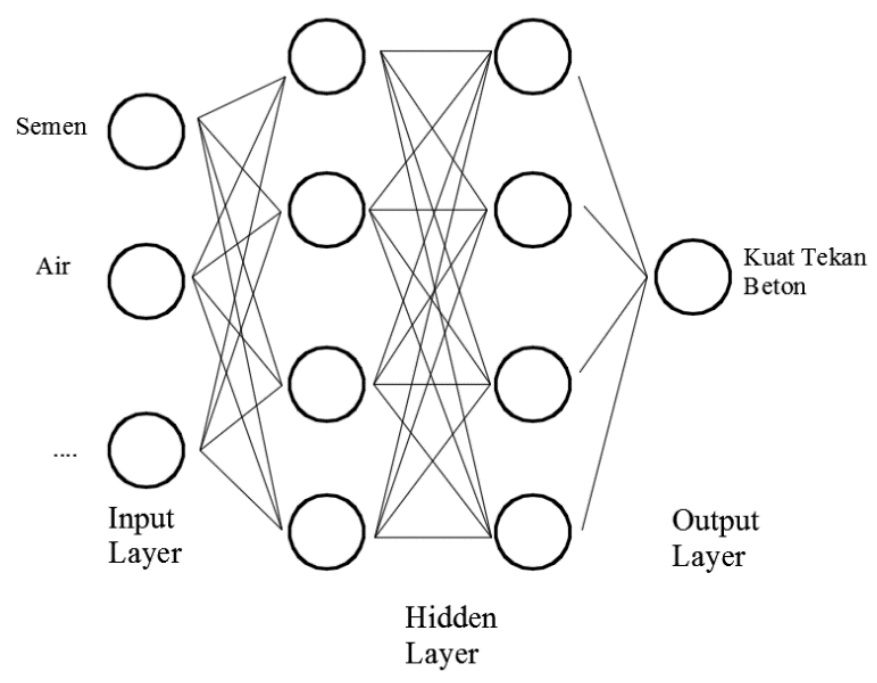

Gambar 1. Ilustrasi struktur ANN

\subsection{Support Vector Machine}

SVM yang dikembangkan oleh Vapnik (1995) sudah banyak digunakan untuk klasifikasi, maupun prediksi. Penggunaan SVM dalam bidang teknik sipil pun juga sudah banyak dilakukan (Cheng, Prayogo, \& Wu, 2013; Cheng, Chou, Roy, \& Wu, 2012). Fungsi Objektif SVM didapatkan dari estimasi fungsi yang diilustrasikan seperti pada Gambar 2 Persamaan linear dari fungsi SVM tersebut adalah $f(x, w)$, yang dapat dilihat pada persamaan berikut:

$$
f(x, \omega)=\sum_{j=1}^{n} w_{j} g_{j}(x)+b
$$

dimana $g_{j}(x)$ adalah kumpulan data transformasi non-linear dari input, dan $b$ adalah bias, dan $w$ adalah pembobotan vektor yang sudah di estimasi. 
Kualitas estimasi SVM dihitung berdasarkan loss function $L_{\varepsilon}$ dimana:

$$
L_{\varepsilon}=L_{\varepsilon}(y, f(x, \omega))=\left\{\begin{array} { c } 
{ 0 } \\
{ | y - f ( x , \omega ) }
\end{array} \quad \left\{\begin{array}{c}
\text { if }|y-f(x, \omega)| \leq \varepsilon \\
\text { otherwise }
\end{array}\right.\right.
$$

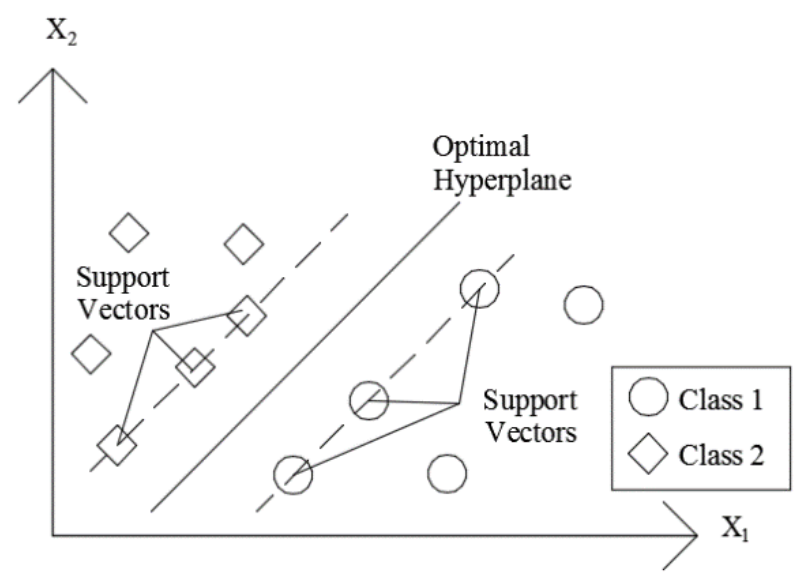

Gambar 2.2. Ilustrasi pemisahan hyperplane dan penentuan support vector oleh SVM

Dalam SVM, LR juga ikut berperan dalam pembentukan regresi dalam feature space dengan menggunakan $\varepsilon$-insensitive loss dan mereduksi kompleksnya pemodelan dengan meminimalkan $/ / \omega / /^{2}$. Maka dari itu, regresi dari SVM dapat di formulasikan sebagai berikut:

$$
\begin{aligned}
& \min \cdot \frac{1}{2}\|\omega\|^{2}+C \sum_{i=1}^{n}\left(\xi_{i}+\xi_{i}^{*}\right) \\
& \text { Subject to }\left\{\begin{array}{l}
y_{i}-f\left(x_{i}, \omega\right) \leq \varepsilon+\xi_{i}^{*} \\
f\left(x_{i}, \omega\right)-y_{i} \leq \varepsilon+\xi_{i} \\
\xi_{i}, \xi_{i}^{*} \geq 0, i=1, \ldots \ldots, n
\end{array}\right.
\end{aligned}
$$

Selanjutnya, permasalahan optimasi yang muncul dalam SVM dapat diselesaikan dengan:

$$
\begin{aligned}
& f(x)=\sum_{i=1}^{n_{s v}}\left(\alpha_{i}-\alpha_{i}^{*}\right) K\left(x, x_{i}\right) \\
& 0 \leq \alpha^{*} \leq C, 0 \leq \alpha_{i}^{*} \leq C
\end{aligned}
$$

dimana $n_{S V}$ adalah bilangan dari support vector. Fungsi kernel-nya adalah:

$$
K\left(x, x_{i}\right)=e^{-\left(\frac{\left\|x-x_{i}\right\|^{2}}{\gamma}\right)}
$$

Selama fase training, fungsi kernel yang terpilih (misalnya linear radial basis, polynomial, atau fungsi sigmoid) digunakan untuk mengidentifikasi support vector pada fungsi. Pengaturan awal kernel-nya tergantung pada tipe dan software yang ter-implementasi. Tujuan dari fungsi kernel ini adalah untuk bisa mengubah fungsi dari dimensi rendah menjadi dimensi yang lebih tinggi agar dapat memisahkan data dengan jelas.

\subsection{Classification and Regression Tree}

CART adalah salah satu Al yang juga digunakan untuk memprediksi suatu kumpulan data. Metode decision tree ini membentuk suatu classification tree dan regression tree tergantung 
dari tipe variabel-nya yang dapat berbentuk numerik atau kategorial. Metode ini pertama kali diusulkan oleh Breiman, Friedman, Stone, \& A. (1984), dimana pada metode ini ditunjukkan bahwa learning tree dapat dioptimasi dengan menggunakan data set untuk memangkas pohon yang sudah jenuh dan memilih dari beberapa pohon yang masih ada.

Beberapa studi sudah dilakukan menggunakan metode CART, dimana pada penelitian terdahulu tersebut tidak hanya dilakukan pada bidang teknik sipil, namun, prediksi dilakukan pada bidang kesehatan, dan bidang transportasi (Kareem, Raviraja, Awadh, Kamaruzaman, \& Kajindran, 2010; Oña, Oña, \& Calvo, 2012; Yang, Liu, Tsoka, \& Papageorgiou, 2017). Metode ini juga mempunyai fitur untuk mencari prediktor dan menentukan nilai ambang batas terbaik pada semua prediktor untuk mengklasifikasikan variabel target (Chou et al., 2014). Algoritma CART mempunyai langkah-langkah sebagai berikut:

1. Penyusunan calon cabang (candidate split), Penyusunan ini dilakukan terhadap seluruh variabel prediktor yang masing-masing dipilah menjadi 2, yaitu calon cabang kiri dan calon cabang kanan.

2. Penilaian kinerja cabang, algoritma ini menilai kinerja keseluruhan calon cabang yang ada pada daftar calon cabang mutakhir. Kinerja dari setiap calon cabang diukur melalui ukuran yang disebut kesesuaian (goodness). Kesesuaian dari calon cabang $s$ pada node keputusan $t$ dilambangkan dengan dan didefinisikan sesuai dengan Persamaan (11) dan (12).

$$
\begin{aligned}
& Q(s \mid t)=\sum_{j=1}^{\text {jumlah kategori }}\left|P\left(j \mid t_{L}\right)-P\left(j \mid t_{R}\right)\right| \\
& \phi(s \mid t)=2 P_{L} P_{R} Q(s \mid t)
\end{aligned}
$$

3. Penentuan calon cabang, algoritma CART adalah menentukan calon cabang manakah yang akan benar-benar dijadikan cabang. Hal ini dilakukan dengan memilih calon cabang yang memiliki nilai kesesuaian $\phi(s / t)$ terbesar. Setelah itu, menggambar percabangan sesuai hasil menjalankan algoritma. Apabila tidak terdapat lagi node keputusan, pelaksanaan algoritma CART akan dihentikan. Namun, jika masih terdapat node keputusan, pelaksanaan algoritma dilanjutkan dengan kembali ke langkah kedua, dengan terlebih dahulu mengeliminasi calon cabang yang telah berhasil menjadi cabang. Ilustrasi mengenai algoritma CART dapat dilihat pada Gambar 3.

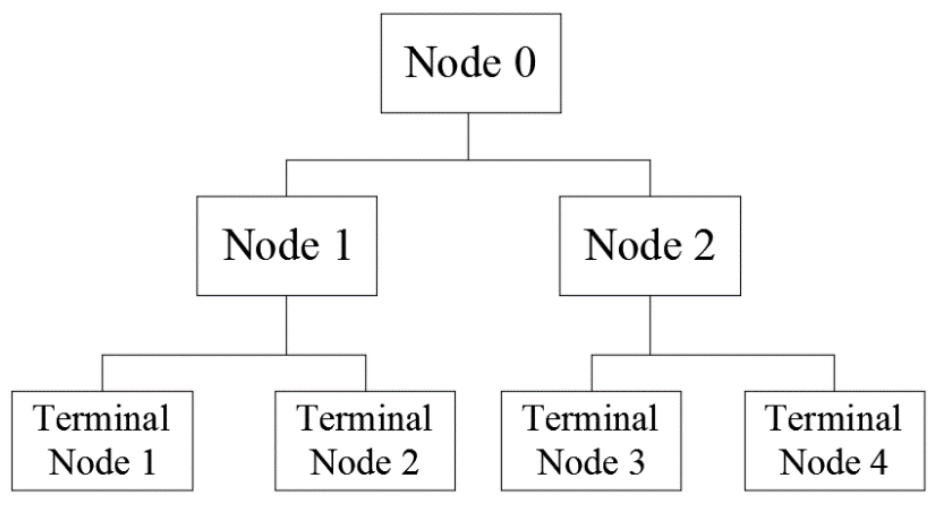

Gambar 3. llustrasi pemodelan menggunakan CART 


\subsection{Metode Evaluasi Model Prediksi}

Untuk menentukan akurat tidaknya hasil prediksi dari $\mathrm{Al}$, digunakan 4 indikator antara lain: coefficient of correlation (R), mean absolute error (MAE), root mean squared error (RMSE), dan mean absolute percentage error (MAPE). Semakin mendekati 1 hasil dari $\mathrm{R}$ maka pemodelan yang dihasilkan semakin akurat. Selain itu, semakin kecil nilai error dari MAE, RMSE, MAPE, maka pemodelan yang dibuat semakin bagus. Untuk merangkum / normalisasi keseluruhan hasil metode evaluasi digunakan Reference Index (RI) sebagai alat pembandingnya (Chou et al., 2011). Nilai RI berkisar antara 0 hingga 1, dimana nilai 1 menggambarkan prediksi yang paling akurat. Perumusan untuk menghitung nilai korelasi, error, dan RI dapat dilihat pada persamaan di bawah ini :

- Coefficient of Correlation

$$
R=\frac{n \sum y \cdot y^{\prime}-\left(\sum y\right)\left(\sum y^{\prime}\right)}{\sqrt{n\left(\sum y^{2}\right)-\left(\sum y\right)^{2}} \sqrt{n\left(\sum{y^{\prime}}^{2}\right)-\left(\sum y^{\prime}\right)^{2}}}
$$

Dimana $y^{\prime}$ adalah nilai prediksi; $y$ adalah nilai aktual; $n$ adalah jumlah data

- Mean Absolute Error

$$
M A E=\frac{1}{n} \sum_{i=1}^{n}\left|y-y^{\prime}\right|
$$

Dimana $y^{\prime}$ adalah nilai prediksi; $y$ adalah nilai aktual; $n$ adalah jumlah data

- Root Mean Squared Error

$$
R M S E=\sqrt{\frac{1}{n} \sum_{i=1}^{n}\left(y^{\prime}-y\right)^{2}}
$$

Dimana $y$ ' adalah nilai prediksi; $y$ adalah nilai aktual; $n$ adalah jumlah data

- Mean Absolute Percentage Error

$$
M A P E=\frac{1}{n} \sum_{i=1}^{n}\left|\frac{y-y^{\prime}}{y}\right|
$$

Dimana $y^{\prime}$ adalah nilai prediksi; $y$ adalah nilai aktual; $n$ adalah jumlah data

- Reference Index

$$
R I=\frac{1}{n} \sum_{i=1}^{n}\left(\frac{P_{i}-P_{\min , i}}{P_{\max , i}-P_{\min , i}}\right)
$$

Dimana $n=j u m l a h$ metode evaluasi ai; $p_{i}=$ nilai ke-i pada 1 metode evaluasi ai

\section{METODOLOGI PENELITIAN}

\subsection{Diagram Alir Penelitian}

Pada sub-bab ini dijelaskan mengenai cara pengambilan, pengolahan dan penyajian hasil prediksi dari data - data yang sudah dikumpulkan. Software untuk aplikasi Al yang digunakan adalah SPSS Clementine 12.0. Gambar 4 menunjukkan gambaran singkat bagaimana proses prediksi ini dilakukan beserta penomoran langkahnya. Langkah pertama yang dilakukan yaitu 
pengumpulan data, dimana pada tahap ini dilakukan pengambilan berbagai mix design yang ada pada jurnal-jurnal internasional yang terpercaya. Langkah kedua, melakukan pemisahan data dimana data tersebut akan dijadikan training dan testing. Pembagian jumlah sampel yang pas merupakan faktor yang penting dalam menghasilkan model prediksi yang tepat. Menurut Hoang \& Nguyen (2018), Hoang \& Tran (2019), dan Prayogo (2018), komposisi training : testing yang dapat digunakan adalah 70:30. Langkah ketiga, pengaturan parameter untuk menemukan model prediksi paling akurat. Langkah keempat, melakukan proses training yang selanjutnya menghasilkan pemodelan untuk masing-masing metode.

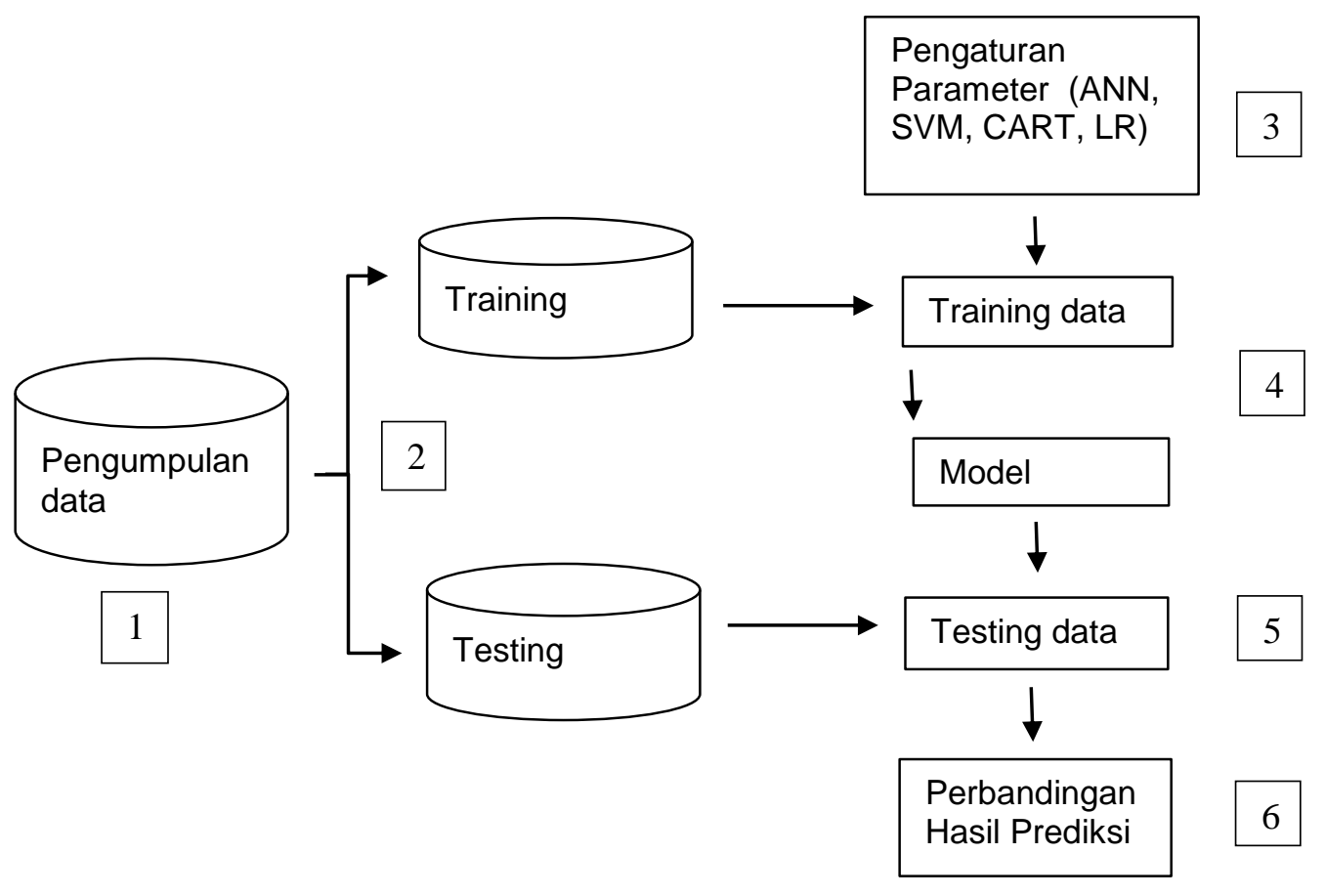

Gambar 4. Diagram alir proses prediksi

Langkah kelima, melakukan proses testing untuk mengetahui apakah pemodelan yang sudah dihasilkan dapat dengan akurat memprediksi kuat tekan beton sesuai dengan kenyataan yang ada. Langkah keenam, membandingkan manakah di antara 4 metode prediksi tersebut yang paling akurat hasil prediksinya dengan cara melihat hasil dari 4 metode evaluasi pada 4 dataset yang sudah terkumpul.

\subsection{Pengumpulan Data}

Pengumpulan data dilakukan dengan cara melakukan pencarian dari jurnal-jurnal yang sudah dipercaya. Keempat data yang dikumpulkan pada penelitian ini melalui proses kimiawi yang sama yaitu reaksi hidrasi. Data pertama diambil dari university of california, irvine repository yang dikumpulkan oleh yeh (1998) dengan kuat tekan beton bervariasi dari 2 hingga 82.6 mpa. Pada data ini terdapat 1030 data yang memiliki 8 variabel input antara lain: cement, blast furnace slag, fly ash (FA), water content (WC), superplasticizer (SP), age, coarse aggregate (C) dan fine aggregate (F). Data kedua diambil dari penelitian yang dilakukan oleh lim, yoon, \& kim (2004). Sebanyak 104 data beton diambil dengan kuat tekan yang bervariasi dari 40 hingga $80 \mathrm{mpa}$. Pada data ini terdapat 6 variabel sebagai input antara lain : FA, WC, 
water/binder ratio, air entraining ratio, SP, F, C. Data ketiga diambil dari penelitian pala et al. (2007) dengan kuat tekan bervariasi dari 8 hingga $107.8 \mathrm{mpa}$. Pada data ini terdapat 144 data dengan 8 variabel sebagai input antara lain: total cementitious material, fa, silica fume, wc, high range water reducing admixture, C, F, age. Data keempat diambil dari penelitian yang dilakukan oleh safarzadegan gilan et al., (2012) dengan kuat tekan bervariasi dari 19 hingga $82.5 \mathrm{mpa}$. Pada data ini terdapat 100 data dengan 6 variabel sebagai input antara lain: cement, metakaolin, WC, C, F, age. Tabel 1 menunjukkan nilai detail dari variabel yang digunakan pada setiap dataset-nya

Tabel 1. Variasi nilai variabel setiap dataset

\begin{tabular}{|c|c|c|c|c|c|c|}
\hline Dataset & Variabel & Satuan & Min. & Ave. & Max & Kriteria \\
\hline \multirow{9}{*}{ Dataset 1} & Cement & $\mathrm{kg} / \mathrm{m}^{3}$ & 102 & 321 & 540 & \multirow{8}{*}{ Input } \\
\hline & Blast furnace slag & $\mathrm{kg} / \mathrm{m}^{3}$ & 0 & 179.7 & 359.4 & \\
\hline & Fly ash & $\mathrm{kg} / \mathrm{m}^{3}$ & 0 & 100.05 & 200.1 & \\
\hline & Water & $\mathrm{kg} / \mathrm{m}^{3}$ & 122 & 184.4 & 247 & \\
\hline & Superplasticizer & $\mathrm{kg} / \mathrm{m}^{3}$ & 0 & 16.1 & 32.2 & \\
\hline & Coarse aggregate & $\mathrm{kg} / \mathrm{m}^{3}$ & 801 & 973 & 1145 & \\
\hline & Fine aggregate & $\mathrm{kg} / \mathrm{m}^{3}$ & 594 & 793.3 & 992.6 & \\
\hline & Age & days & 1 & 183 & 365 & \\
\hline & $\begin{array}{l}\text { Concrete compressive } \\
\text { strength }\end{array}$ & $\mathrm{MPa}$ & 2 & 42.45 & 82.6 & Output \\
\hline
\end{tabular}

\begin{tabular}{|c|c|c|c|c|c|c|}
\hline \multirow{7}{*}{ Dataset 2} & Water to binder ratio & $\%$ & 30 & 37.5 & 45 & \multirow{6}{*}{ Input } \\
\hline & Water content & $\mathrm{kg} / \mathrm{m}^{3}$ & 160 & 170 & 180 & \\
\hline & Fine aggregate ratio & $\%$ & 37 & 45 & 53 & \\
\hline & Fly ash ratio & $\%$ & 0 & 10 & 20 & \\
\hline & Air entraining ratio & $\mathrm{kg} / \mathrm{m}^{3}$ & 0 & 0.057 & 0.078 & \\
\hline & Superplasticizer & $\mathrm{kg} / \mathrm{m}^{3}$ & 2 & 5.195 & 8.5 & \\
\hline & $\begin{array}{l}\text { Concrete compressive } \\
\text { strength }\end{array}$ & $\mathrm{MPa}$ & 38 & 56 & 74 & Output \\
\hline
\end{tabular}


Tabel 1 (lanjutan). Variasi nilai variabel setiap dataset

\begin{tabular}{|c|c|c|c|c|c|c|}
\hline Dataset & Variabel & Satuan & Min. & Ave. & Max & Kriteria \\
\hline \multirow{9}{*}{ Dataset 3} & $\begin{array}{l}\text { Fly ash replacement } \\
\text { ratio }\end{array}$ & $\%$ & 0 & 27.5 & 55 & \multirow{8}{*}{ Input } \\
\hline & $\begin{array}{l}\text { Silica fume } \\
\text { replacement ratio }\end{array}$ & $\%$ & 0 & 2.5 & 5 & \\
\hline & $\begin{array}{l}\text { Total cementitious } \\
\text { material }\end{array}$ & $\mathrm{kg} / \mathrm{m}^{3}$ & 400 & 450 & 500 & \\
\hline & Fine aggregate & $\mathrm{kg} / \mathrm{m}^{3}$ & 536 & 630 & 724 & \\
\hline & Coarse aggregate & $\mathrm{kg} / \mathrm{m}^{3}$ & 1086 & 1121.5 & 1157 & \\
\hline & Water content & $\mathrm{It} / \mathrm{m}^{3}$ & 150 & 177.5 & 205 & \\
\hline & $\begin{array}{l}\text { High range water } \\
\text { reducing admixture }\end{array}$ & $\mathrm{It} / \mathrm{m}^{3}$ & 0 & 6.5 & 13 & \\
\hline & Age & days & 3 & 91.5 & 180 & \\
\hline & $\begin{array}{l}\text { Concrete compressive } \\
\text { strength }\end{array}$ & $\mathrm{MPa}$ & 8 & 57.8 & 107.8 & Output \\
\hline \multirow{7}{*}{ Dataset 4} & Cement & $\mathrm{kg} / \mathrm{m}^{3}$ & 320 & 360 & 400 & \multirow{6}{*}{ Input } \\
\hline & Coarse aggregate & $\mathrm{kg} / \mathrm{m}^{3}$ & 765 & 859.5 & 954 & \\
\hline & Fine aggregate & $\mathrm{kg} / \mathrm{m}^{3}$ & 54.7 & 536.1 & 1017.5 & \\
\hline & Water content & $\mathrm{kg} / \mathrm{m}^{3}$ & 140 & 170 & 200 & \\
\hline & Metakaolin & $\mathrm{kg} / \mathrm{m}^{3}$ & 0 & 40 & 80 & \\
\hline & Age & days & 7 & 93.5 & 180 & \\
\hline & $\begin{array}{l}\text { Concrete compressive } \\
\text { strength }\end{array}$ & $\mathrm{MPa}$ & 19 & 50.75 & 82.5 & Output \\
\hline
\end{tabular}

\subsection{Pengaturan Parameter}

Pengaturan parameter diperlukan agar hasil yang didapatkan dari prediksi tetap terkontrol dan tidak abstrak. Selain itu, tujuan adanya pengaturan parameter ini untuk mengevaluasi pengaturan parameter metode prediksi yang dapat menghasilkan prediksi yang paling akurat. Pengaturan parameter diaplikasikan untuk 3 jenis Al yang digunakan pada penelitian ini, diantaranya: artificial neural network (ANN), support vector machine (SVM), dan classification and regression tree (CART). Karena LR adalah regresi linier, maka tidak diperlukan pengaturan parameter tambahan. Pengaturan parameter yang digunakan metode LR hanya pengaturan parameter standar dari software.

Pengaturan parameter yang digunakan pada penelitian ini adalah pengaturan parameter standar dari SPSS Clementine 12.0 dan terdapat beberapa perubahan pengaturan parameter yang menganut kaidah grid search. Tabel 2 mendeskripsikan standar pengaturan parameter 
dari setiap metode prediksi yang digunakan, sedangkan nomor 1 pada akhiran nama metode prediksi menjelaskan bahwa Al tersebut berjalan dengan pengaturan parameter standar.

Tabel 2. Pengaturan parameter standar pada SPSS Clementine 12.0

\begin{tabular}{|c|c|c|}
\hline $\begin{array}{l}\text { Metode } \\
\text { Prediksi }\end{array}$ & Parameter & Pengaturan \\
\hline \multirow{5}{*}{ ANN1 } & Prevent Over training & TRUE \\
\hline & Alpha & 0.9 \\
\hline & Presistence & 200 \\
\hline & Hidden Layer & 1 \\
\hline & Number of Hidden Neuron & 20 \\
\hline \multirow{4}{*}{ SVM1 } & Epsilon & 1 \\
\hline & Kernel & RBF \\
\hline & Regularization Parameter, C & 10 \\
\hline & RBF Gamma & 0.1 \\
\hline \multirow{5}{*}{ CART1 } & Levels Below Root & 5 \\
\hline & Max Surrogates & 5 \\
\hline & Change in Impurity & 0.0001 \\
\hline & Impurity Measure & Gini \\
\hline & Prune Tree & TRUE \\
\hline \multirow{3}{*}{ LR1 } & Collinearity Diagnostics & FALSE \\
\hline & Regression Coefficients & TRUE \\
\hline & Singularity Tolerance & $1,0 \mathrm{E}-4$ \\
\hline
\end{tabular}

Sumber: pengaturan parameter standar dari SPSS Clementine 12.0

Grid search adalah metode sederhana yang dapat digunakan untuk optimasi suatu parameter. Metode ini menggabungkan 2 himpunan parameter dengan bantuan produk kartesius untuk menemukan suatu kombinasi parameter baru. Untuk metode ANN, parameter yang diubah adalah number of hidden layer dan number of hidden neurons. Himpunan dari parameter tersebut adalah:

$$
\begin{array}{ll}
\text { number of hidden layers } & =\{1,2,3\} \\
\text { number of hidden neurons } & =\{8,13,17\}
\end{array}
$$

Satu himpunan parameter disusun dalam sumbu $X$ dan yang lainnya disusun dalam sumbu Y. Al melakukan training dengan parameter yang sudah diubah sesuai titik-titik kombinasi 
pada sumbu kartesius. Dari 1 pengaturan standar SPSS Clementine 12.0 dan 9 pengaturan menggunakan grid search, didapatkanlah total 10 kombinasi yang digunakan pada metode ANN.

Sedangkan untuk metode SVM, parameter yang diubah adalah nilai dari C (regularization parameter) dan nilai dari $\gamma$ (gamma). Himpunan dari parameter $\mathrm{C}$ dan $\gamma$ adalah:

$$
\begin{array}{ll}
C & =\{1,10,100\} \\
\gamma & =\{0.01,0.1,1\}
\end{array}
$$

Satu himpunan parameter disusun dalam sumbu $X$ dan yang lainnya disusun dalam sumbu Y. Al melakukan training dengan parameter yang sudah diubah sesuai titik-titik kombinasi pada sumbu kartesius. Dari 1 pengaturan standar SPSS Clementine 12.0 dan 9 pengaturan menggunakan grid search, didapatkanlah total 10 kombinasi yang digunaakan pada metode SVM.

Pada metode CART parameter yang diubah adalah parameter "levels below root". Sedangkan, himpunan dari parameter "levels below root" adalah:

$$
\text { Levels below root } \quad=\{6,7,8\}
$$

Dari 1 pengaturan standar SPSS Clementine 12.0 dan 3 pengaturan menggunakan grid search, didapatkanlah total 4 kombinasi yang digunakan pada metode CART.

Semua pengaturan parameter ini diaplikasikan pada keempat dataset yang terkumpul, setelah itu dilakukan evaluasi metode prediksi dengan parameter manakah yang punya performa paling bagus memprediksi beragam tipe dataset.

\section{HASIL DAN PEMBAHASAN}

Berdasarkan semua data yang diperoleh pada setiap dataset, maka pada tahap ini digabungkan semua hasil terbaik pada semua dataset untuk tiap metode prediksi. Tabel 3 menjelaskan mengenai keseluruhan model prediksi yang paling akurat dalam memprediksi 4 dataset. Selanjutnya, dari hasil yang diperoleh dilakukan pembandingan lalu diambil kesimpulan, metode prediksi manakah yang paling bagus untuk memprediksi berbagai macam campuran beton. 
Tabel 3. Ranking setiap metode pada setiap dataset

\begin{tabular}{|c|c|c|c|c|c|c|c|c|}
\hline \multirow[b]{2}{*}{ Dataset } & \multirow{2}{*}{\multicolumn{2}{|c|}{$\begin{array}{l}\text { Model } \\
\text { Prediksi }\end{array}$}} & \multicolumn{4}{|c|}{ Metode Evaluasi Model Prediksi } & \multirow[b]{2}{*}{$\mathbf{R} \mathbf{I}$} & \multirow[b]{2}{*}{ RANK } \\
\hline & & & $\mathbf{R}$ & $\begin{array}{c}\text { MAE } \\
(\mathrm{MPa})\end{array}$ & $\begin{array}{l}\text { RMSE } \\
\text { (MPa) }\end{array}$ & $\begin{array}{c}\text { MAPE } \\
(\%)\end{array}$ & & \\
\hline \multirow{4}{*}{ Dataset 1} & ANN & 6 & 0.944 & 4.193 & 5.589 & $14.76 \%$ & 1.000 & 1 \\
\hline & SVM & 10 & 0.91 & 5.150 & 7.02 & $18.77 \%$ & 0.759 & 2 \\
\hline & CART & 4 & 0.88 & 6.147 & 8.074 & $21.68 \%$ & 0.555 & 3 \\
\hline & LR & 1 & 0.795 & 8.290 & 10.303 & $34.77 \%$ & 0.000 & 4 \\
\hline \multirow{4}{*}{ Dataset 2} & ANN & 4 & 0.988 & 0.937 & 1.288 & $1.77 \%$ & 0.975 & 1 \\
\hline & SVM & 1 & 0.989 & 1.015 & 1.284 & $1.92 \%$ & 0.878 & 2 \\
\hline & CART & 1 & 0.978 & 1.251 & 1.766 & $2.40 \%$ & 0.000 & 4 \\
\hline & LR & 1 & 0.984 & 1.199 & 1.514 & $2.39 \%$ & 0.312 & 3 \\
\hline \multirow{4}{*}{ Dataset 3} & ANN & 10 & 0.962 & 4.380 & 6.229 & $10.71 \%$ & 1.000 & 1 \\
\hline & SVM & 10 & 0.927 & 6.821 & 8.74 & $17.98 \%$ & 0.614 & 3 \\
\hline & CART & 4 & 0.959 & 5.198 & 6.539 & $14.03 \%$ & 0.900 & 2 \\
\hline & LR & 1 & 0.848 & 10.549 & 12.091 & $28.40 \%$ & 0.000 & 4 \\
\hline \multirow{4}{*}{ Dataset 4} & ANN & 8 & 0.882 & 5.002 & 6.201 & $12.12 \%$ & 1.000 & 1 \\
\hline & SVM & 7 & 0.812 & 6.135 & 8.016 & $16.82 \%$ & 0.464 & 2 \\
\hline & CART & 1 & 0.727 & 6.658 & 9.471 & $20.04 \%$ & 0.051 & 4 \\
\hline & LR & 1 & 0.772 & 7.085 & 8.504 & $17.98 \%$ & 0.212 & 3 \\
\hline
\end{tabular}

Dari hasil penelitian, ANN sebagai model prediksi memiliki hasil yang lebih bagus bila dibandingkan dengan metode lainnya. Hal ini diperkuat dengan nilai RI pada ANN mempunyai nilai yang paling tinggi bila dibandingkan dengan metode lainnya. Meskipun ANN mempunyai hasil prediksi paling akurat, model prediksi ANN terbaik pada setiap dataset tidak konsisten. Hal ini dapat dilihat pada dataset 1, model ANN terbaik adalah ANN6. Pada dataset 2, 3, dan 4, model ANN terbaik adalah ANN4, 10, dan 8. Sejalan dengan hasil pada ANN, dapat dilihat bahwa pada dataset 1, model SVM terbaik adalah SVM 10. Sedangkan pada dataset 2, SVM terbaik adalah SVM 1. Di sisi lain CART4 pada dataset 3 juga memiliki hasil yang terbaik dibandingkan dengan CART pada dataset 4. Dari hasil ini, maka setiap metode memerlukan pengaturan parameter yang tepat untuk mendapatkan hasil paling akurat. Karena setiap pengaturan parameter tidak selalu memberikan hasil yang optimal untuk setiap dataset.

Penelitian yang dilakukan oleh Prayogo (2018) dan Yeh (1998), menggunakan dataset dari Yeh (1998), membuktikan bahwa ANN mampu menunjukkan hasil prediksi yang lebih bagus 
bila dibandingkan dengan metode SVM dan LR. Hal ini juga ditemukan pada penelitian yang dilakukan oleh Chopra, Sharma, Kumar, \& Chopra (2018) dan Yeh \& Lien (2009), dimana data beton yang dipakai masing-masing sebanyak 147 dan 1196 data. ANN pada penelitian tersebut juga menunjukkan hasil prediksi yang lebih akurat bila dibandingkan dengan tree method. Berdasarkan penelitian diatas, terlihat bahwa hasil ANN lebih baik dari metode lainnya. Menurut Geyikçi, Kiliç, Çoruh, \& Elevli (2012), Hal ini disebabkan ANN tidak memerlukan desain eksperimen standar dalam membuat suatu pemodelan. Selain itu, ANN cenderung fleksibel untuk membangun suatu model prediksi yang akurat. Maka dari itu, ANN memiliki potensi untuk membuat suatu pemodelan lebih bagus bila dibandingkan dengan metode SVM, CART, LR dalam memprediksi kuat tekan beton

Gambar 5 menyajikan gabungan nilai error pada setiap metode untuk mengetahui metode manakah yang memiliki nilai error terkecil. Guna memvisualisasikan tingkat akurasi dari masing-masing metode terhadap masing-masing dataset, penelitian ini menggunakan MAE kuat tekan beton prediksi dan kuat tekan beton aktual. Nilai dari MAE dipilih karena MAE merupakan nilai rata-rata error yang sebenarnya dari hasil prediksi. Dari Gambar 4.17 dapat diketahui bahwa error dari ANN memiliki nilai yang terkecil dibandingkan dengan metode prediksi lainnya untuk keseluruhan dataset. Hal ini membuktikan bahwa ANN merupakan AI yang memiliki performa paling baik dalam memprediksi kuat tekan beton. Di sisi lain, secara umum error dari LR memiliki nilai yang paling besar, hal ini mengindikasikan bahwa LR adalah metode yang paling buruk dalam memprediksi kuat tekan beton.

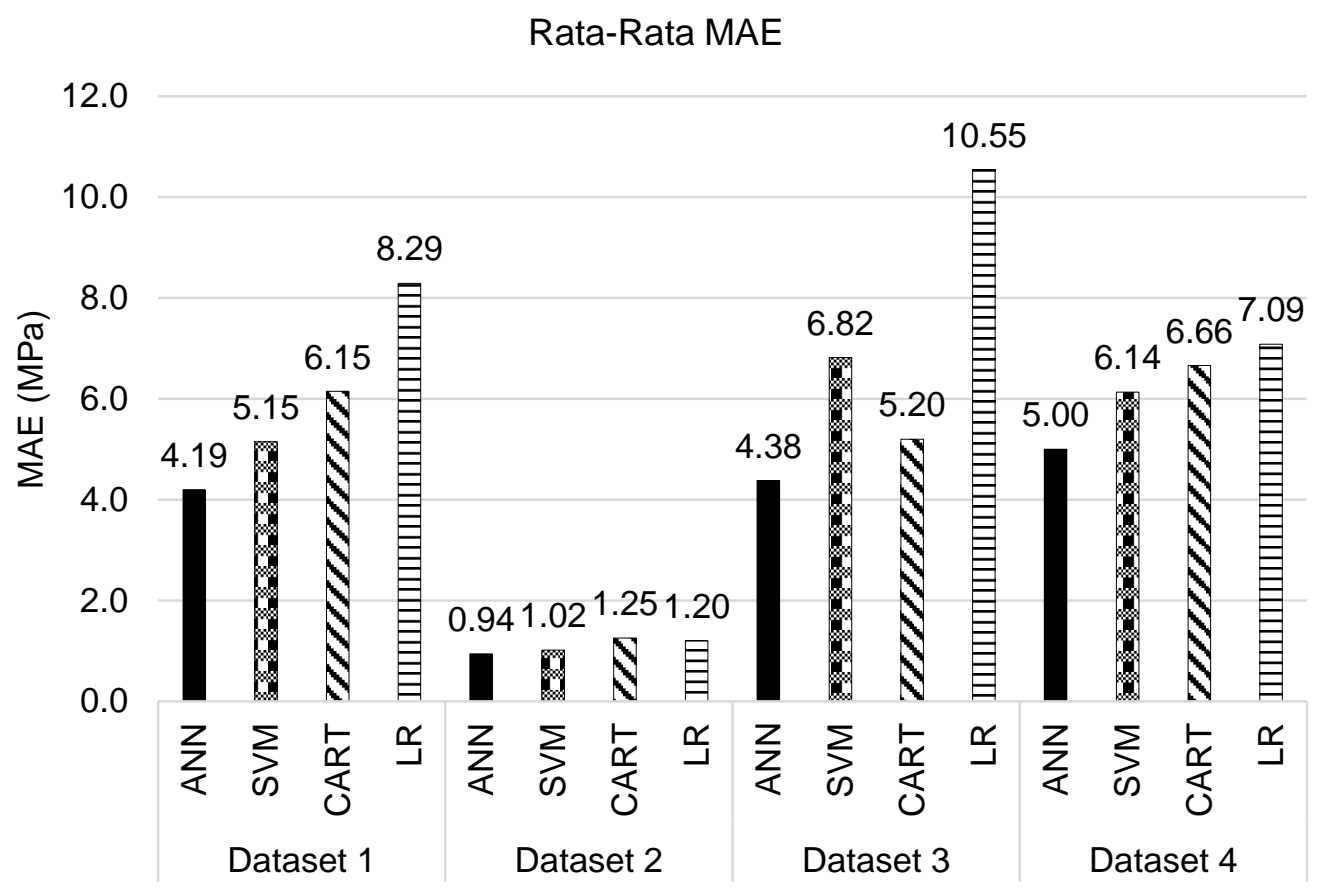

Gambar 5. Visualisasi rata-rata nilai error metode prediksi untuk semua dataset

\section{KESIMPULAN}

Penelitian ini menyajikan studi mengenai perbandingan antar 3 metode Al dan 1 metode tradisional dalam memprediksi 4 tipe campuran beton atau dataset. Metode-metode prediksi yang digunakan meliputi ANN, SVM, CART, dan LR. Keempat dataset diambil dari jurnal 
independen dan terpercaya untuk menjaga keaslian data. Beberapa dataset ini dibuat model prediksi dan diuji tingkat akurasi model dalam memprediksi data baru. Cara pengukuran akurasi model prediksi digunakan empat buah indikator evaluasi yang terdiri dari R, MAE, MAPE, RMSE. Selain itu, RI juga digunakan untuk normalisasi nilai dari indikator evaluasi metode prediksi untuk mengetahui metode prediksi mana yang memiliki tingkat prediksi yang lebih baik.

Maka, berdasarkan pengaturan parameter yang menggunakan grid search dan beberapa pilihan parameter yang sudah ditentukan dalam penelitian ini, dapat ditarik kesimpulan bahwa ANN adalah metode prediksi yang memiliki performa paling akurat dalam memprediksi kuat tekan beton bila dibandingkan dengan metode prediksi lainnya.

\section{DAFTAR REFERENSI}

Azimi-Pour, M., \& Eskandari-Naddaf, H. (2018). ANN and GEP prediction for simultaneous effect of nano and micro silica on the compressive and flexural strength of cement mortar. Construction and Building Materials, 189, 978-992. https://doi.org/10.1016/j.conbuildmat.2018.09.031

Behnood, A., \& Golafshani, E. M. (2018). Predicting the compressive strength of silica fume concrete using hybrid artificial neural network with multi-objective grey wolves. Journal of Cleaner Production, 202, 54-64. https://doi.org/10.1016/j.jclepro.2018.08.065

Breiman, L., Friedman, J., Stone, C. J., \& A., O. R. (1984). Classification and regression trees. New York: Chapman \& Hall/CRC.

Cheng, M.-Y., Chou, J.-S., Roy, A. F. V., \& Wu, Y.-W. (2012). High-performance concrete compressive strength prediction using time-weighted evolutionary fuzzy support vector machines inference model. Automation in Construction, 28, 106-115. https://doi.org/10.1016/j.autcon.2012.07.004

Cheng, M.-Y., Firdausi, P. M., \& Prayogo, D. (2014). High-performance concrete compressive strength prediction using Genetic Weighted Pyramid Operation Tree (GWPOT). Engineering Applications of Artificial Intelligence, 29, 104-113. https://doi.org/10.1016/j.engappai.2013.11.014

Cheng, M.-Y., Prayogo, D., \& Wu, Y.-W. (2013). Novel genetic algorithm-based evolutionary support vector machine for optimizing high-performance concrete mixture. Journal of Computing in Civil Engineering, 28(4), 06014003. https://doi.org/10.1061/(asce)cp.19435487.0000347

Chopra, P., Sharma, R. K., Kumar, M., \& Chopra, T. (2018). Comparison of machine learning techniques for the prediction of compressive strength of concrete. Advances in Civil Engineering, 2018. https://doi.org/https://doi.org/10.1155/2018/5481705

Chou, J.-S., Farfoura, M., Chiu, C.-K., \& Altaharwa, I. (2011). Optimizing the prediction accuracy of concrete compressive strength based on a comparison of data-mining techniques. Journal of Computing in Civil Engineering, 30(4), 1-11. https://doi.org/10.1061/(ASCE)CP.1943-5487

Chou, J.-S., Tsai, C.-F., Pham, A.-D., \& Lu, Y.-H. (2014). Machine learning in concrete strength simulations: Multi-nation data analytics. Construction and Building Materials, 73, 
771-780. https://doi.org/10.1016/j.conbuildmat.2014.09.054

Duval, R., \& Kadri, E. H. (1998). Influence of silica fume on the workability and the compressive strength of high-performance concretes. Cement and Concrete Research, 28(4), 533547.

Eskandari, H., Nik, M. G., \& Eidi, M. M. (2016). Prediction of mortar compressive strengths for different cement grades in the vicinity of sodium chloride using ANN. Procedia Engineering, 150, 2185-2192. https://doi.org/10.1016/j.proeng.2016.07.262

Geyikçi, F., Kiliç, E., Çoruh, S., \& Elevli, S. (2012). Modelling of lead adsorption from industrial sludge leachate on red mud by using RSM and ANN. Chemical Engineering Journal, 183, 53-59. https://doi.org/10.1016/j.cej.2011.12.019

Hammoudi, A., Moussaceb, K., Belebchouche, C., \& Dahmoune, F. (2019). Comparison of artificial neural network (ANN) and response surface methodology (RSM) prediction in compressive strength of recycled concrete aggregates. Construction and Building Materials, 209, 425-436. https://doi.org/10.1016/j.conbuildmat.2019.03.119

Hoang, N. D., \& Nguyen, Q. L. (2018). Metaheuristic optimized edge detection for recognition of concrete wall cracks: A comparative study on the performances of Roberts, Prewitt, Canny, and Sobel algorithms. Advances in Civil Engineering, 2018. https://doi.org/10.1155/2018/7163580

Hoang, N. D., \& Tran, V. D. (2019). Image Processing-Based Detection of Pipe Corrosion Using Texture Analysis and Metaheuristic-Optimized Machine Learning Approach. Computational Intelligence and Neuroscience, 2019. https://doi.org/10.1155/2019/8097213

Kabir, A., Hasan, M., \& Miah, K. (2012). Predicting 28 days compressive strength of concrete from 7 days test result. Proceedings of Conference on Advances in Design and Construction of Structures, (June 2014), 18-22. https://doi.org/02.ADCS.2012.1.505.18.3. a4.

Kareem, S. A., Raviraja, S., Awadh, N. A., Kamaruzaman, A., \& Kajindran, A. (2010). Classification and regression tree in prediction of survival of AIDS patients. Malaysian Journal of Computer Science, 23(3), 153-165. https://doi.org/10.22452/mjcs.vol23no3.2

Khademi, F., Akbari, M., Jamal, S. M., \& Nikoo, M. (2017). Multiple linear regression, artificial neural network, and fuzzy logic prediction of 28 days compressive strength of concrete. Frontiers of Structural and Civil Engineering, 11(1), 90-99. https://doi.org/10.1007/s11709-016-0363-9

Khosravani, M. R., Nasiri, S., Anders, D., \& Weinberg, K. (2019). Prediction of dynamic properties of ultra-high performance concrete by an artificial intelligence approach. Advances in Engineering Software, 127(October 2018), 51-58. https://doi.org/10.1016/j.advengsoft.2018.10.002

Lim, C. H., Yoon, Y. S., \& Kim, J. H. (2004). Genetic algorithm in mix proportioning of highperformance concrete. Cement and Concrete Research, 34(3), 409-420. https://doi.org/10.1016/j.cemconres.2003.08.018

Oña, J. De, Oña, R. De, \& Calvo, F. J. (2012). A classification tree approach to identify key factors of transit service quality. Expert Systems with Applications, 39(12), 11164-11171. https://doi.org/10.1016/j.eswa.2012.03.037 
Pala, M., Özbay, E., Öztaş, A., \& Yuce, M. I. (2007). Appraisal of long-term effects of fly ash and silica fume on compressive strength of concrete by neural networks. Construction $\begin{array}{lll}\text { and Building } \quad \text { Materials, } & \text { 384-394. }\end{array}$ https://doi.org/10.1016/j.conbuildmat.2005.08.009

Prayogo, D. (2018). Prediksi kuat tekan beton menggunakan metode artificial intelligence. Penguasaan Teknologi Dan Bahasa Asing Dalam Menghadapi Pertumbuhan Ekonomi Dunia Di Era Revolusi Industri 4.0, 33-38. Surabaya.

Prayogo, D., Wong, F. T., \& Tjandra, D. (2018). Prediction of high-performance concrete strength using a hybrid artificial intelligence approach. MATEC Web of Conferences, 203. https://doi.org/10.1051/matecconf/201820306006

Rosenblatt, F. (1958). The perceptron: A probabilistic model for information storage and organization in the brain. Psychological Review, 65(6), 386-408. https://doi.org/10.1037/h0042519

Safarzadegan Gilan, S., Bahrami Jovein, H., \& Ramezanianpour, A. A. (2012). Hybrid support vector regression - Particle swarm optimization for prediction of compressive strength and RCPT of concretes containing metakaolin. Construction and Building Materials, 34, 321-329. https://doi.org/10.1016/j.conbuildmat.2012.02.038

Topçu, I. B., \& Saridemir, M. (2008). Prediction of compressive strength of concrete containing fly ash using artificial neural networks and fuzzy logic. Computational Materials Science, 41(3), 305-311. https://doi.org/10.1016/j.commatsci.2007.04.009

Vapnik, V. (1995). The nature of statistical learning theory. Springer-Verlag New York, Inc.

Yang, L., Liu, S., Tsoka, S., \& Papageorgiou, L. G. (2017). A regression tree approach using mathematical programming. Expert Systems with Applications, 78, 347-357. https://doi.org/10.1016/j.eswa.2017.02.013

Yeh, I. (1998). Modeling of strength of high-performance concrete using artificial neural networks. Cement and Concrete Research, 28(12), 1797-1808.

Yeh, I., \& Lien, L. (2009). Knowledge discovery of concrete material using genetic operation trees. Expert systems with applications, 36(3 part 2), 5807-5812. https://doi.org/10.1016/j.eswa.2008.07.004 